\title{
Subterranean clover (Trifolium subterraneum): its history and current and future research in New Zealand
}

\author{
M.L. SMETHAM \\ 75 a Aikmans Road, Merivale, Christchurch \\ arborsand@clear.net.nz
}

\begin{abstract}
This review covers the history of subterranean clover (Trifolium subterraneum) and its present occurrence in New Zealand; a review of research and conclusions to be drawn from this; and examines past and future research directions.
\end{abstract}

Subterranean clover has been important in terms of area of use in New Zealand since the late 1930's. Today it makes a significant contribution to pasture production on steep, north-facing North Island hill country where effective rainfall is low, and in other areas where soil moisture drops below wilting point for between 2 weeks and 5 months of the year.

Research has identified the superiority of cultivars possessing a compact, ground-hugging habit of growth, and flowering late, in late October - early November, for use in North Island hill country. In drier areas, more research is needed to identify superior cultivars, although there is evidence that lines in the mid-season or early mid-season flowering groups may be appropriate. A major problem for the use of subterranean clovers in New Zealand is the slow breakdown of hardseededness.

About $7 \mathrm{M}$ ha of land in New Zealand is mapped as being subject to slight to severe moisture deficit (an area which could with advantage support subterranean clover), but further research is needed to identify appropriate cultivars for $4.8 \mathrm{M}$ ha or more of this area.

Key words: history, New Zealand, research, Trifolium subterraneum

\section{History of subterranean clover use in New Zealand}

Subterranean clover (Trifolium subterraneum) was first recognised in New Zealand in the early 1900s growing near Auckland, where it became known as Mangere clover (Saxby 1956). Its arrival may have been associated with the transport of live sheep to the new colony, although A. W. Howard of South Australia is quoted as having "distributed seeds to all parts of Australia, New Zealand and South Africa" prior to 1906 . The species was regarded as a weed until the mid-1920s, but from the late 1930s it was being sown on much easy to rolling country. (Saxby 1956). In 1936, Levy \& Gorman reported the herbage production of 15 cultivars obtained from Australia. Some, including the late flowering 'Nangeela', were superior to late flowering 'Tallarook' and late midseason flowering 'Mount Barker', but the latter two were recommended because they were the only cultivars commercially available at the time. The development of hill country by oversowing during the Depression, and later the advent of aerial oversowing from 1947 onwards, caused a substantial increase in the use of subterranean clover (Saxby 1956).

The plant received a considerable boost after Professor E. R. Hudson, Principal of Lincoln College, returned from study leave in Australia in 1930, convinced that it was the ideal plant for the shallow stony soils of the Canterbury plains.

Subsequent research (Calder 1954) and promotion by the College resulted in the development of a highly successful farming system. This took advantage of the high winter-early spring growth rates of subterranean clover enabling lambing very early in July and selling lambs prime before herbage dried off in mid-November.

Subterranean clover sown at $2-4 \mathrm{~kg} / \mathrm{ha}$, and the new perennial ryegrass proved to be much more productive than the annual types of white clover and ryegrass that farmers had been using prior to this, and carrying capacity was increased threefold (Calder 1951). However, in the 1960s, grazed lucerne was shown to be more than twice as productive as pastures based on subterranean clover (Iversen 1965). So interest in subterranean clover waned and a whole generation of young farmers grew up with scant knowledge of how to best manage the plant.

Subterranean clover is frequently only sparsely distributed in pasture, on many but not all soils where moisture drops below wilting point in summer for 
anything from 2 weeks to 5 months. The species occurs widely on the sunny aspect of North Island hill country where it occupies the steep slope areas that have lower fertility and less moisture than the easier country (Ledgard et al.1987). It is less prevalent in South Island hill country probably because of the overall drier conditions. Suckling et al. (1983) found that the late mid-season flowering 'Mt Barker', and late flowering 'Tallarook' were the predominant cultivars present during a survey of North and South Island hill country.

Management of these pastures on the hill country, and much of the flat, consists of close and continuous grazing during and after lambing, with periods of setstocking and spelling during the rest of the year. Today, subterranean clover survives on most cultivable dryland properties and on hill country, although often making only a small contribution to pasture production, and with less than ideal management. Given the right management, and appropriate cultivars, subterranean clover can survive better and produce more herbage than many other legumes in dryland regions (Davies 1952).

\section{Research results with subterranean clover cultivars}

\section{Herbage production}

Initially, research was limited to comparisons of herbage productivity of cultivars, (Levy \& Gorman 1936; McLeod 1967; Smetham 1968; Harris et al.1973) but whilst differences have been recorded, e.g. Dodd et al. (1995c), those between cultivars flowering at the same time are small. Later flowering cultivars will always produce higher herbage yields, if moisture allows (Scott 1969), because of the greater number of nodes bearing leaves before flowering assumes priority for assimilates (Rossiter 1959). For example Widdup \& Pennell (2000) record a continual increase of productivity from $2500 \mathrm{~kg} \mathrm{DM} /$ ha for early, to 7 $300 \mathrm{~kg} \mathrm{DM} /$ ha for late flowering cultivars in the first (wet) season of their comparison.

Used as the legume component in a mixed sward, or sown pure, subterranean clover can result in a substantial increase in productivity. Calder (1951) records carrying capacity increasing from 0.62 ee/ha on an unimproved Canterbury dryland sward to 6.25 ee/ha on a subterranean clover ryegrass pasture. A long term average for the subterranean clover component on these flat, stony, shallow, dryland soils is $23 \%$ of the total dryland pasture production of 5
$870 \mathrm{~kg} \mathrm{DM} /$ ha (Rickard \& Radcliffe 1976). Smetham \& Jack (1995) recorded more than $5000 \mathrm{~kg}$ DM/ha produced annually from hard grazed pure swards of mid-season to late flowering cultivars on similar soils in Canterbury, compared with only $764 \mathrm{~kg} \mathrm{DM} /$ ha from a naturally occurring unimproved sward consisting of striated clover (Trifolium striatum), cluster clover (Trifolium glomeratum), haresfoot trefoil (Trifolium arvense), and vulpia (Vulpia bromoides).

On hill country in Canterbury, a pure sward of laxly grazed Woogenellup produced over $6000 \mathrm{~kg} \mathrm{DM} / \mathrm{ha}$ in 1978 (White \& Meijer 1979). Typical production from North Island hill country is recorded by Ledgard et al. (1987) who found that subterranean clover yielded $1100-1500 \mathrm{~kg} \mathrm{DM} /$ ha out of a total $5300-6$ $400 \mathrm{~kg} \mathrm{DM} / \mathrm{ha}$. These figures apply to discreet parts of this landscape only. Subterranean clover was found only on gentle and steep slopes with a northerly aspect, and was associated with the lowest values for any landform of moisture in summer, and available levels of P and K. From similar landscape units, Sheath \& Boom (1985a) obtained a three year mean of 6130 $\mathrm{kg} \mathrm{DM} /$ ha from swards where subterranean clover was the main legume. On sunny face country improved by the introduction of legumes, including subterranean clover, with fertiliser, Suckling (1959) recorded $2700 \mathrm{~kg} \mathrm{DM} /$ ha from unimproved, to 6300 $\mathrm{kg} \mathrm{DM} /$ ha for improved areas, with an increase from $3.7 \mathrm{ee} / \mathrm{ha}$ to $13.6 \mathrm{ee} / \mathrm{ha}$ in carrying capacity.

A major advantage of subterranean clover is its coolseason growth, well ahead of comparative plots of lucerne over the same periods (Table 1, Smetham \& Jack 1995) and superior to published rates of winter growth (4-15 kg DM/ha/d) for one of the most winter active of perennial grasses i.e. 'Grasslands Maru' phalaris (Stevens et al. 1989). This pattern of growth fits in well with a midwinter lambing date.

\section{Factors influencing success with subterranean clover}

\section{Adequate seedling population in autumn}

Subterranean clover has been oversown by air in New Zealand at $2-4 \mathrm{~kg} / \mathrm{ha}$ on hill country, and included in seed mixtures at a similar rate when drilled into worked ground.

However, this rate is totally inadequate for the establishment of an effective plant population, particularly as the individual seed weight is more than 10 times greater than that of white clover, which is normally sown at $3 \mathrm{~kg} / \mathrm{ha}$. Dear \& Sandral (1997) 
Table 1 Rates of green herbage accumulation ( $\mathrm{kg} \mathrm{DM} / \mathrm{ha} / \mathrm{d})$ during the cool season for 'Otaio' Lucerne and a mean rate for six numbered accessions of subterranean clover during 1995 (Smetham \& Jack 1995).

\begin{tabular}{lcccc}
\hline Period & 12.04 to 5.08 & & 6.08 to 13.09 & 14.09 to 12.10 \\
Lucerne $^{1}$ & $4.9^{2}$ & 17.1 & 10.1 \\
Period & 6.04 to 17.05 & 29.05 to 2.08 & 10.08 to 7.09 & 19.09 to 7.10 \\
Subterranean clover & 19.6 & 11.6 & 20.4 & 48.2 \\
\hline
\end{tabular}

${ }^{1}$ Measured monthly using the Australian difference technique.

2 See original paper for statistical analysis.

recommend $7 \mathrm{~kg} / \mathrm{ha}$ as a minimum rate for subterranean clover, whilst recognising that it will take several years to obtain an adequate seedling population from reestablishment each autumn. Dear et al. (1993) found that more than adequate seedling numbers were achieved in the third year after an initial sowing of $25 \mathrm{~kg} / \mathrm{ha}$.

Many Australian authors, e.g. Silsbury \& Fukai (1977), suggest that 1000 seedlings $/ \mathrm{m}^{2}$ at germination in autumn is necessary if maximum herbage production is to be obtained from a pure sward. In New Zealand, Smetham \& Jack (1995) found that herbage production was strongly correlated with seedling numbers in autumn $(\mathrm{r}=0.70 \mathrm{P}<0.001)$, with populations in excess of $1700 / \mathrm{m}^{2}$ resulting in the greatest herbage production of $4000-5000 \mathrm{~kg} / \mathrm{ha}$. Both Williams et al. (1990) and Sheath \& Macfarlane (1990a) obtained a similar linear relationship between DM production and seedling numbers in hill country. Adequate seedling populations are only obtained by sowing realistic amounts of seed (viz. 7-25 kg/ha) or being prepared to wait a year or two; with appropriate management to allow full establishment by spelling during germination each autumn. Sheath \& Macfarlane (1990b) have found that 2000 seeds $/ \mathrm{m}^{2}$ are required in February to produce the 200 seedlings/ $\mathrm{m}^{2}$ in June, that Sheath \& Macfarlane (1990a) considered necessary to maximise herbage production of a mixed grass clover sward in North Island summer dry hill country.

Establishing seedlings in mixed swards can face considerable competition for moisture from the grass component. Therefore it is vital for legume success to minimise such competition. On cultivable ground this can be achieved by topworking subterranean clover - grass paddocks every third year using grubber, discs or heavy harrows in mid-summer (Calder 1954). Grime et al. (1990) classify this legume as a near-ruderal species, indicating that it does not cope well with competition. In terms of autumn seedling numbers, Dear \& Cocks (1997) found only two clover seedlings $/ \mathrm{m}^{2}$ survived to 15 May from an early March germination when subterranean clover was associated with perennial companion plants; 37 survived with annual companions, but over 950 seedlings $/ \mathrm{m}^{2}$ survived when subterranean clover was grown as a pure sward. On hill country, control of companion grasses must be obtained by rotating hard, clean-up grazing around a small number of paddocks in summer and autumn, repeating this on any one paddock once every 3 years (Emmersen 1980).

Recently germinated seedlings are easily killed by grazing below the junction of stem and the two cotyledon leaves. Therefore defoliation should not be too close.

Newly germinated stands should ideally be spelled from grazing for 3-5 weeks to allow leaf area to build up (Silsbury \& Fukai 1977), since this has a compounding effect on cool season growth (Hoglund \& Pennell 1989)

Flowering early enough to set seed before drought The majority of research with subterranean clover in New Zealand has centred on the selection of cultivars that will flower, set, and mature sufficient seed before soils reach wilting point. Australian research has shown that for this to be achieved, flowering needs to start 70 to 80 days before dryness curtails growth (Dear \& Sandral 1997, Rossiter 1978).

The start of flowering is governed mainly by the amount of cold required to initiate flower production (Aitken 1955). Early flowering ecotypes have little requirement for cold and therefore flower in early spring, but late flowering ecotypes require exposure to 6-10 weeks of days with temperatures below $10^{\circ} \mathrm{C}$ 
Table 2 Characteristics of subterranean clover cultivars recommended for use in New South Wales (after Dear \& Sandral 1997).

\begin{tabular}{|c|c|c|c|c|}
\hline Cultivar & $\begin{array}{c}\text { Flowering } \\
\text { commences }\end{array}$ & $\begin{array}{l}\text { Days from sowing } \\
\text { in mid-May to } \\
\text { flowering (d) }\end{array}$ & $\begin{array}{l}\text { Minimum annual } \\
\text { rainfall for } \\
\text { persistence }(\mathrm{mm})\end{array}$ & $\begin{array}{c}\text { Hardseed in } \\
\text { autumn } O=\text { nil, } \\
5=\text { high }\end{array}$ \\
\hline Nungarin & early August & 110 & 375 & 5 \\
\hline Dalkeith & late August & 120 & 400 & 5 \\
\hline Seaton Park L & early September & 125 & 475 & 3 \\
\hline York & early September & 125 & 475 & 5 \\
\hline Trikkala & early September & 122 & 525 & 2 \\
\hline Riverina & mid-September & 128 & 500 & 3 \\
\hline Rosedale & mid-September & 120 & 500 & 3 \\
\hline Gosse & late September & 136 & 650 & 3 \\
\hline Junee & mid September & 138 & 500 & 3 \\
\hline Woogenellup & mid September & 140 & 525 & 2 \\
\hline Clare & late September & 142 & 650 & 2 \\
\hline Goulburn & late September & 145 & 525 & 3 \\
\hline Denmark & early October & 149 & 600 & 2 \\
\hline Leura & early October & 156 & 750 & 1 \\
\hline Nuba & early October & 152 & 700 & 3 \\
\hline
\end{tabular}

All the above cultivars are low to very low in formononetin.

Rainfall figures are a guide only and will vary with aspect, slope and soil type in Australia.

The flowering data are based on observations at Wagga Wagga, New South Wales.

Much additional information is available in Dear \& Sandral (1997).

before initiation occurs and therefore they do not commence flowering until early summer. Table 2 lists Australian cultivars currently recommended for use in New South Wales. The flowering dates listed are some 3 weeks ahead of that occurrence in Canterbury (Widdup \& Pennell 2000). Cultivars are usually grouped according to whether they flower "early", or in "early mid-season", "mid-season", "late midseason, or "late". Table 4 includes both current and superceded Australian cultivars, grouped according to flowering period.

The ability to reseed adequately is of paramount importance, and Scott (1969) confirmed the Australian experience that cultivars must flower sufficiently early to allow adequate seed to mature before drought sets in. In a grass-clover sward the 200 seedlings $/ \mathrm{m}^{2}$ required for North Island hill country equates to seed production of about $120-160 \mathrm{~kg} / \mathrm{ha}$ depending on seed weight. Carter \& Cochrane (1985) cite $200 \mathrm{~kg} / \mathrm{ha}$ as being a necessary seed reserve for a mid-season flowering cultivar in 500-600 $\mathrm{mm}$ annual rainfall areas in Australia. After accounting for all losses of seed and seedlings from initial germination, false strike, consumption of burrs by grazing animals, and hardseededness, Smetham (2003) suggested that for a pure sward to achieve 1,000 seedlings $/ \mathrm{m}^{2}$, early, mid-season and late flowering lines need to set 336 , 288 and $218 \mathrm{~kg} / \mathrm{ha}$ of seed, respectively.

In a mixed sward seed production is strongly inhibited by associated perennials. This is caused by a reduction of light reaching the clover, rather than lack of moisture. This can lead to a $50 \%$ reduction of seed yield in 2 out of 3 years (Dear et al. 2000).

In the following accounts, seedling numbers and the weight of seed produced are used as measures of how successful a cultivar is. A considerable amount 
of research has concentrated on North Island, New Zealand hill country. This is surprising, considering the average annual rainfall in these areas is often between 900 and $1700 \mathrm{~mm}$ (Williams et al. 1990). However, much of this country is steep, and more than $50 \%$ of the rainfall runs off and is ineffective (Bircham \& Gillingham 1986). In addition, from 3 to 5 moisture deficits typically occur in bursts of 1 to 2 weeks with rain between, from late November to early February (Lambert \& Roberts 1976). This low effective rainfall predicates the use of subterranean clover, while periodic mid to late summer rain suggests that late flowering strains could be successful. Much research has shown this to be the case e.g. Macfarlane \& Sheath (1984) and others (Chapman et al. 1986), with the late mid-season flowering 'Mount Barker' and late flowering 'Tallarook' being the most successful. It has been shown that over time there has been a shift in the flowering time of these naturalised populations to be later for 'Mt Barker', and earlier for 'Tallarook' (Macfarlane \& Sheath 1984). The optimum flowering time to obtain maximum seed and seedling numbers is now considered to be late October to early November (Sheath \& Macfarlane 1990a).

Over the 1980's, an evaluation of nine named Australian cultivars was conducted at eight sites (Figure 1) throughout New Zealand (Williams et al. 1990).

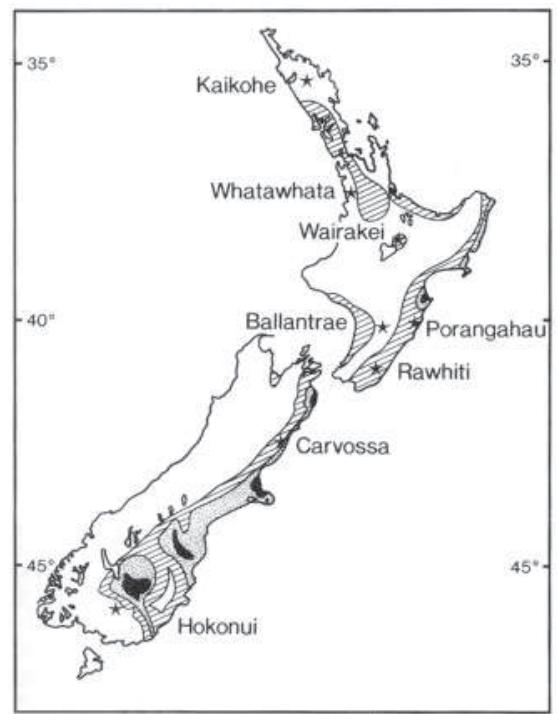

Figure 1 Location of trial sites and zones of annual average soil moisture deficits: $\square, 0-50$ $\mathrm{mm} ; \mathbb{\nabla}, 50-100 \mathrm{~mm}$; 圈, 100-200 mm; $200 \mathrm{~mm}+$.
At Whatawhata (Sheath \& Macfarlane 1990a), on steep hill country with a rainfall of $1600 \mathrm{~mm}$, and with continuous close grazing management, the midseason 'Howard', the late mid-season 'Mt Barker' and particularly the late flowering 'Tallarook' produced seedling numbers in June that approached the optimum of 200 seedlings $/ \mathrm{m}^{2}$. The success of late flowering cultivars indicates adequate moisture for seed production from the start of flowering in late October up to the end of December. In addition, herbage yields were highest for these cultivars. However, under rotational grazing, early mid-season 'Seaton Park' and 'Trikkala', mid-season 'Woogenellup' and 'Clare', and late flowering 'Nangeela' and 'Larissa' mostly exceeded the optimum number of plants $/ \mathrm{m}^{2}$ in June, and produced more herbage than 'Mt Barker' or 'Tallarook'. The former cultivars, like many Australian selections, have an "open" habit, characterised by long internodes, a low population of large leaves carried on long petioles, and runners that do not hug the ground. Under close and continuous grazing these cultivars are heavily denuded of runners, flowers and burrs, penalising herbage and seed production. 'Mt Barker' and 'Tallarook' are the reverse in terms of growth habit, being small leaved, with a dense crown and prostrate runners (Sheath \& Macfarlane 1990b). In some years, there was up to $60 \%$ loss of seed from false strike (Sheath \& Macfarlane 1990a), also recorded by Dodd et al. (1995a), which would indicate a lack of dry conditions to promote hardseededness during seed maturation (Quinliven 1971). False strike is a characteristic of late flowering cultivars (Quinliven \& Millington 1962), which typically have low levels of hardseededness (Table 3). The results at Ballantrae (Chapman \& Williams 1990) were almost identical to those noted for Whatawhata. Again cultivars with an open growth habit, were disadvantaged by close grazing.

In spite of this, one of them, 'Nangeela', produced almost as many seedlings as 'Tallarook'. Under rotational grazing 'Trikkala', 'Seaton Park' and 'Howard' produced the highest seedling numbers, although not the highest dry matter yields. Generally, the outcome was much the same at Porangahau, with 700-900 mm annual rainfall (Sheath et al. 1990), where 'Tallarook' produced the largest reserve of seed in one year, equivalent to about $430 \mathrm{~kg} / \mathrm{ha}$. It did this also at Wairakei with $1250 \mathrm{~mm}$ rainfall on free-draining sandy pumice soils (Macfarlane et al. 1990), 
Table 3 The proportion of hard seed possessed by nine cultivars of subterranean clover at seed maturity, after four months exposure to summer temperatures in the field in Western Australia, and after six months of exposure in an oven to a diurnal fluctuating temperature regime of $15{ }^{\circ} \mathrm{C}$ night/ $60{ }^{\circ} \mathrm{C}$ day temperatures (Quinliven \& Millington 1961).

\begin{tabular}{lccc}
\hline Cultivar $^{1}$ & $\begin{array}{c}\text { Early summer } \\
\% \text { hard }\end{array}$ & $\begin{array}{c}\text { Four months in the field } \\
\% \text { hard }\end{array}$ & $\begin{array}{c}\text { Six months in the oven } \\
\% \text { hard }\end{array}$ \\
\hline Geraldton & 97.0 & 64.7 & 29.3 \\
Dwalganup & 96.5 & 62.4 & 10.3 \\
Burnerang & 82.4 & 52.4 & 28.8 \\
Carnamah & 95.5 & 51.2 & 8.5 \\
Morocco & 80.7 & 35.3 & 26.4 \\
Woogenellup & 86.0 & 34.4 & 2.8 \\
Palestine & 89.2 & 29.6 & 3.1 \\
Baccus Marsh & 71.0 & 16.5 & 0.2 \\
Mount Barker & 58.8 & 11.1 & 2.1 \\
\hline
\end{tabular}

${ }^{1}$ In sequential order of first flower appearance from 'early' to 'late mid-season' flowering.

On the very different winterwet soils overlying a pan, and with an annual rainfall of $1589 \mathrm{~mm}$ at Kaikohe, the subspecies $T$ s. yanninicum cultivars: 'Trikkala' and 'Larissa', were predictably superior. Cultivars in this subspecies are tolerant of winter waterlogging, and were superior in yield of herbage and regeneration, with seedling densities of 500-1 200/m² compared to 'Mount Barker' and 'Tallarook' with only 200/m² (Rumball \& Cooper 1990).

Dodd et al. (1995a) followed up their earlier work on North Island summer dry hill country by examining the persistence of 45 lines, flowering a month earlier to four days later than 'Tallarook'. Two lines and one blend from a North Island collection gave highest total herbage yield. However five lines and one Australian breeding line were significantly better at regeneration than 'Tallarook', and achieved 400 established plants $/ \mathrm{m}^{2}$ on the steep aspect country in June. False strike ranged from $2-60 \%$. The late midseason flowering 'Karridale' performed similarly to 'Tallarook'. Other named cultivars were inferior. Dodd et al. (1995c) obtained much the same result in another evaluation, recording the highest values of 400-2 000 $\mathrm{kg} /$ ha for total seed production of three North Island lines and an Australian breeding line-all exceeding 'Tallarook'. Buried seed, measured in March, and hence regarded as hard seed, was $21-69 \%$ of the total. An evaluation on drier pumice hill country (Dodd et al. 1995b) gave an almost identical result, but with the addition of 'Karridale' to the top performing lines.

At a high rainfall site (1 $292 \mathrm{~mm})$ in the Hokonui hills in Southland, a high seedset resulted for all cultivars in the first autumn, but no hard seed was formed, and second year regeneration was minimal (Widdup \& Turner 1990). However, at Carvossa in North Canterbury, with only $657 \mathrm{~mm}$ average rainfall, and soils below wilting point from late November, under periodic grazing (Hoglund 1990), the highest seed yields of $68-400$ seeds $/ \mathrm{m}^{2}$ were produced by the 'Trikkala' and 'Howard'. Yields were considerably less for late-flowering cultivars. Seedling numbers, however, were lower (68-285 seedlings $\left./ \mathrm{m}^{2}\right)$ than seed numbers would indicate because of the high level of hardseededness (60-92\%) amongst the earlier cultivars (Smetham \& Wu Ying 1991). Although this figure may have been inflated by losses of seedlings from insect predation and false strike, Smetham (1980) also measured high levels of hardseededness (70$80 \%$ ) from a similar dry North Canterbury hill country site near Culverden in each of two years. At this site, 'Seaton Park' was superior, but early flowering 'Geraldton' and 'Northam A', and 'Woogenellup' all set adequate to large amounts of seed (2 $000-8000$ seeds $/ \mathrm{m}^{2}$ or $130-450 \mathrm{~kg} / \mathrm{ha}$ ). In spite of high hardseed, adequate to high numbers of seedlings (240-2 500/ $\mathrm{m}^{2}$ ) were evident in late autumn. On similar country near Waipara in North Canterbury, Scott (1969) also found 'Geraldton' gave the highest seed yields 
Table 4 Australian cultivars of subterranean clover, grouped according to the date of start of flowering, together with current status in New South Wales, and where not recommended, the main reason for relegation, and the recommended replacement (after Dear \& Sandral 1997).

\begin{tabular}{|c|c|c|c|}
\hline Flowering Group & Cultivar & Status/reason for relegation & Replacement \\
\hline \multirow[t]{6}{*}{ Early } & Nungarin & Recommended & \\
\hline & Dwalganup & High oestrogen & Nungarin \\
\hline & Geraldton & High oestrogen & Nungarin \\
\hline & Northam & Outclassed & Nungarin; Dalkeith \\
\hline & Dalkeith & Recommended & \\
\hline & Daliak & Aphid prone & Dalkeith \\
\hline \multirow[t]{5}{*}{ Early mid-season } & Seaton Park LF & Recommended & \\
\hline & York & Recommended & \\
\hline & Yarloop & High oestrogen & Trikkala \\
\hline & Dinninup & High oestrogen & Riverina \\
\hline & Howard & High oestrogen & Woogenellup \\
\hline \multirow[t]{9}{*}{ Mid-season } & Trikkala & Recommended & \\
\hline & Riverina & & \\
\hline & Rosedale & Recommended & \\
\hline & Esperance & Recommended & \\
\hline & Junee & Outclassed & \\
\hline & Woogenellup & Recommended & Junee; Riverina \\
\hline & Enfield & Root disease prone & Junee; Riverina \\
\hline & Green Range & Low hardseededness & Junee; Riverina \\
\hline & Bacchus Marsh & Leaf disease prone & Denmark \\
\hline \multirow[t]{6}{*}{ Late mid-season } & Gosse & Recommended & \\
\hline & Goulburn & Recommended & \\
\hline & Denmark & Recommended & \\
\hline & Clare & Recommended & \\
\hline & MtBarker & Leaf and root disease prone & Denmark; Leura \\
\hline & Karridale & Outclassed & Denmark \\
\hline \multirow[t]{4}{*}{ Late } & Leura & Recommended & \\
\hline & Larisa & Outclassed & Gosse \\
\hline & Meteora & Outclassed & Gosse \\
\hline & Tallarook & High oestrogen & Leura \\
\hline
\end{tabular}

although 'Woogenellup' and the mid-season flowering subspecies $T s$. brachycalycinum 'Clare' produced over $500 \mathrm{~kg} / \mathrm{ha}$ seed. 'Mt Barker' and 'Tallarook' had much lower seed yields. Predictably the highest herbage yield was from cultivars that grew long enough to exploit available moisture until its disappearance. Thus, 'Geraldton' dried off too soon.

Recently, Widdup \& Pennell (2000) evaluated a large number of mid to late flowering lines including 15 Australian cultivars covering the full range of flowering time, and the latest cultivars to be released. The evaluation occurred in a $650 \mathrm{~mm}$ average annual rainfall area near Christchurch. In the first year, with higher than average spring and summer rainfall, most lines including mid-season flowering 'Junee', late midseason flowering 'Goulburn', and 'Karridale', set large amounts of seed ranging from $350-600 \mathrm{~kg} / \mathrm{ha}$, confirming as reported, that moisture was adequate well into the summer. This also resulted in low levels of hard seed (19-28\%). Regeneration in later years of this evaluation however was poor, except for the late flowering, small leaved and prostrate cultivars 'Denmark' and 'Leura', and one selection from the North Island which established 50\% more seedlings 
and gave $25 \%$ more herbage than 'Mount Barker' or 'Tallarook'. Almost as good were the Sardinian ecotypes, one prostrate Whatawhata line and 'Junee'. However in the succeeding drier years with only half the average spring and summer rainfall, midseason flowering lines including 'Junee' were best. An evaluation on a shallow Templeton soil near Lincoln in Canterbury (Smetham et al. 1993) where soil moisture drops below wilting point in mid November until sometime in March, supported the idea that early or early mid-season flowering lines are required under drier conditions. Measurements made 4 years after sowing on periodically heavily grazed plots of 42 early to late flowering accessions and five Australian cultivars showed that 22 lines produced seed reserves greater than $250 \mathrm{~kg} / \mathrm{ha}$. These lines, including 'Geraldton', were all in the early, or early mid-season flowering groups.

Lines and cultivars flowering later, including 'Seaton Park' and 'Tallarook' averaged only around $80 \mathrm{~kg} / \mathrm{ha}$ seed. Thirty-seven lines had hardseededness exceeding 50\%. However there were 11 lines which produced both seed reserves of $250 \mathrm{~kg} / \mathrm{ha}$ or more and at least 1000 seedlings $/ \mathrm{m}^{2}$.

Because of the variable nature of the New Zealand climate, a subsequent comparison at a nearby site in 1993 (Smetham et al. 1994) gave a very different result. This was because May, June and July experienced less than half normal rainfall, September was very wet with $133 \mathrm{~mm}$ instead of the normal $50 \mathrm{~mm}$ rainfall, October very dry with only $9 \mathrm{~mm}$ rainfall, and November rainfall was $90 \mathrm{~mm}$ or nearly twice normal. As a result, early and early mid-season flowering cultivars failed to recover after the October drought and set little seed. However, four mid-season accessions produced $97-184 \mathrm{~kg} / \mathrm{ha}$ seed, and two late flowering numbered accessions produced the highest seedset of $216-270 \mathrm{~kg} / \mathrm{ha}$. The eight most successful lines, which included 'Tallarook', were characterised by the ability to 'kick-on', or recommence flowering after drought, that was strongly correlated with seed yield $(r=0.65 \mathrm{P}<0.01)$. Scott (1985) has recorded high levels of seed production from subterranean clovers on shallow dry soils in the Mackenzie Basin, but subsequent performance was not recorded.

\section{High levels of germinable seed in autumn}

The seed of all varieties of subterranean clover can possess high to very high (50-90\%) levels of hardseededness at early maturity (Tables 2 \& 3) if conditions are sufficiently dry such that seeds dry to less than 5-7\% moisture during maturation (Quinliven 1971). This mechanism prevents seed from germinating with rain in summer only to die in dry conditions thereafter.

Hard seed is unable to germinate because of an inability to imbibe water. Hardseededness declines with time (Quinliven \& Millington 1962), depending on variety and the diurnal amplitude of temperature fluctuation (Table 3). In most areas of subterranean clover use in Australia, under a temperature regime of high day temperatures of $40-50{ }^{\circ} \mathrm{C}$ and a diurnal variation of $>15{ }^{\circ} \mathrm{C}$, hardseededness declines by autumn to allow germination of 50\% (early flowering varieties) and 95\% (late flowering varieties) (Table 3 ). In New Zealand such temperatures can occur (Sheath \& Boom 1985b) but are unusual and hardseededness declines more slowly (Smetham \& Wu Ying 1991) as a result of lower maximum temperatures and a low diurnal variation. High levels of hardseededness in naturally produced seed, ranging from $70-72 \%$ in 'Woogenellup' and 'Seaton Park', to nearly $80 \%$ for 'Northam A' and 'Geraldton' have been reported from hot dry North Canterbury (Smetham 1980) resulting in low autumn germination of $21-23 \%$. Hardseededness is required initially at and after seed maturation, since premature germination in summer rains followed by dry conditions can cause heavy seed and seedling losses (Macfarlane \& Sheath 1984; Sheath \& Macfarlane 1990b; Dodd et al.1995c). Hardseededness is accentuated with earlier flowering lines because they mature seed under increasingly dry conditions and hence seed possesses greater hardseededness. There is no current solution to this problem, although selection for a faster rate of breakdown under cooler conditions is possible. Success with selection should be assured since considerable variation exists within ecotypes (Smith et al. 1996). An alternative approach is to select for very high seed production, because adequate seed will germinate subsequently even though hardseededness is high (Smetham et al. 1993).

\section{Future research with subterranean clover}

A priority for future subterranean clover research is to find suitable cultivars for the drier parts of New Zealand. Whilst suitable cultivars can be recommended for the North Island hill country in Zone 2 in Figure 1 (perhaps $2.2 \mathrm{M} \mathrm{ha}$ ), no findings are available for the balance of this zone (perhaps $2 \mathrm{M}$ ha) in the South Island. There remains concern for Zone 3 (2.32 M ha) and no work in depth has been 
conducted in Zone $4(0.53 \mathrm{M}$ ha). The latter two areas total $2.85 \mathrm{M}$ ha, which approximates the $2.7 \mathrm{M}$ ha estimate by Maunder (1971) of land with a "slight to considerable deficit", and equates to more than $10 \%$ of New Zealand's total land area. Some of this land is already supporting swards with subterranean clover as a constituent, but much of this area is supporting no more than an ephemeral mix of annual clovers and grasses with an annual productivity of less than 1 $000 \mathrm{~kg} \mathrm{DM} / \mathrm{ha}$ (Smetham \& Jack 1995).

Lines chosen for testing should come from areas identified as having climates as similar as possible to those where they will be used in New Zealand. To do this, climate classification and matching tools (e.g. Russell \& Moore 1970) should be used to indicate which parts of the Old World might provide suitable germplasm. This will enable an approach to be made to the Australian Trifolium Genetic Resource Centre at Perth, since it is highly likely that material from such areas will already be catalogued and available.

The second priority must be selection for a rapid decline of hardseededness to achieve $60 \%$ or greater germination by 30 March, or the selection of lines with very high levels of seed production.

In the future, testing of accessions must be done in the areas where these will be used. A good model of testing procedure is that of the Australian National Subterranean Clover Improvement Programme system (Collins 1987) where initial screening is done at base, with subsequent general evaluation of many lines being done in areas of potential use before a few final selections are subjected to more detailed testing.

To enable both the interpretation of research findings and the extension of results to practice it is essential that in future the moisture regime during trials is adequately documented, ideally recording daily rainfall and evapotranspiration to enable soil water budgets to be calculated.

\section{Conclusions}

\section{Herbage production}

- Introduction of subterranean clover has been shown to more than double production from unimproved sunny aspect North Island hill country, and more than quadruple that from unimproved dryland in the South Island.

- The contribution from subterranean clover in existing pastures could be increased by greater attention to management.
- Subterranean clover has the ability to grow substantially faster than lucerne and perennial grasses in winter and early spring.

\section{Choice of cultivar}

- For North Island hill country with low effective rainfall, 'Karridale' with 'Denmark' or 'Leura' are recommended.

- On gumland soils with wet, poorly drained conditions over winter 'Trikkala' and 'Gosse' are recommended.

- On Canterbury hill and similar country with 600$700 \mathrm{~mm}$ annual rainfall (Zone 3, Figure 1) 'Seaton Park LF' (low oestrogen) and 'Junee' are recommended.

- For flat to rolling country with deep soils in Zone 3, 'Denmark' or 'Leura' should be used with either 'Goulburn' or 'Junee'.

- For shallow soils in Zone 3, where moisture disappears early in the season 'Seaton Park' and 'Riverina' may be suitable.

- There is insufficient data on which to base recommendations for the driest areas of the South Island (Zone 4).

\section{Management Issues}

- Sowing at least $9 \mathrm{~kg} / \mathrm{ha}$ of seed, and avoiding close grazing during autumn establishment and early winter growth are required to promote herbage yield and adequate annual reseeding.

- Subterranean clover grown as a pure sward has been shown to produce a yield equal to that from a grass-clover sward.

- The use of current recommended cultivars may be associated with the retention of high levels of hardseededness in autumn, leading to suboptimal seedling populations.

- Future research priorities are firstly the selection of germplasm with a faster rate of decline in hardseededness under New Zealand conditions, and secondly the identification of cultivars suitable for the driest areas of the South Island.

\section{REFERENCES}

Aitken, Y. 1955. Factors affecting flower initiation in Trifolium subterraneum L. Australian Journal of Agricultural Research 6: 212-244.

Bircham, J.S.; Gillingham, A.G. 1986. A water balance model for sloping land. New Zealand Journal of 
Agricultural Research 29: 315-323.

Calder, J.W. 1951. Investigations into the production of subterranean clover pastures on Ashley Dene 1939-1946. Lincoln College Technical Publication No 6. 52 pp.

Calder, J.W. 1954. Subterranean clover pastures on light land. Canterbury Chamber of Commerce Agricultural Bulletin 301. 4pp.

Carter, E.D.; Cochrane, M.J. 1985. The poor subterranean clover status of dairy pastures in the Adelaide hills. pp. 217-219. In: Proceedings of the 3rd Australian Agronomy Conference.

Chapman, D.F.; Sheath, G.W.; Macfarlane, M.J.; Rumball, P.J.; Cooper, B.M.; Crouchley, G.; Hoglund, J.H.; Widdup, K.G. 1986. Performance of subterranean and white clover varieties in dry hill country. Proceedings of the New Zealand Grassland Association 47: 53-62.

Chapman, D.F.; Williams, W.M. 1990. Evaluation of clovers in dry hill country 8 . Subterranean clover at "Ballantrae", New Zealand. New Zealand Journal of Agricultural Research 33: 569-576.

Collins, W.J. 1987. Structure and organisation of the National Subterranean Clover Improvement Programme. pp. 1-4. In: Proceedings of the third National Subterranean Clover Improvement Programme.

Davies, J.G. 1952. Pastures in the Australian Economy. Journal of the Australian Institute of Agricultural Science 18: 60-67.

Dear, B.S.; Cregan, P.D.; Murray, G.M. 1993. Comparison of the performance of subterranean clover cultivars in southern New South Wales. 1. Persistence, productivity and seed yields. Australian Journal of Agricultural Research 33: 581-590.

Dear, B.S.; Cocks, P.S. 1997. Effect of perennial pasture species on surface soil moisture and early growth and survival of subterranean clover (Trifolium subterraneum L.) seedlings. Australian Journal of Agricultural Research 48: 683-693.

Dear, B.S.; Sandral, G.A. 1997. Subterranean clover in NSW-identification and use. Agfact P 2.5.16. Second edition. New South Wales Agriculture, Sydney. 36 pp.

Dear, B.S.; Cocks, P.S.; Swan, A.D.; Wolfe, E.C.; Ayre, L.M. 2000. Effect of phalaris (Phalaris aquatica L.) and lucerne (Medicago sativa L.) density on seed yield and regeneration of subterranean clover (Trifolium subterraneum L.). Australian Journal of Agricultural Research 51: 267-278.

Dodd, M.B.; Sheath, G.W.; Richardson, S. 1995a. Development of subterranean clover (Trifolium subterraneum L.) genotypes for New Zealand pastures 1. Whatawhata persistence evaluation. New Zealand Journal of Agricultural Research 38: 33-48.

Dodd, M.B.; Sheath, G.W.; Richardson, S. 1995b. Development of subterranean clover (Trifolium subterraneum L.) genotypes for New Zealand pastures 2. Wairakei persistence evaluation. New Zealand Journal of Agricultural Research 38: 49-56.

Dodd, M.B.; Sheath, G.W.; Tarbotton, I.S. 1995c. Development of Trifolium subterraneum L. genotypes for New Zealand pastures 3 . Whatawhata production evaluation. New Zealand Journal of Agricultural Research 38: 57-63.

Emmersen, R.S. 1980. Managing and developing dry hill country. pp. 347-357. In: Proceedings of the 29th Lincoln College Farmers' Conference.

Grime, J.P.; Hodgson, J.G.; Hunt, R. 1990. Comparative plant ecology. Unwin Wyman. London. 400 pp.

Harris, A.J.; Brown, K.R.; Turner, J.D.; Johnston, J.M.; Ryan, D.L.; Hickey, M.J. 1973. Some factors affecting pasture growth in Southland. New Zealand Journal of Experimental Agriculture 1: 139-163.

Hoglund, J.H. 1990. Evaluation of clovers in dry hill country 1. Subterranean clover in North Canterbury, New Zealand. New Zealand Journal of Agricultural Research 33: 585-590.

Hoglund, J.H.; Pennell, C.G.L. 1989. Autumn nitrogen fertilizer in a dryland sheep system. Proceedings of the New Zealand Grassland Association 50: 135-138.

Iversen, C.E. 1965. Lucerne: Its potentiality and methods of achieving its potentiality. pp. 78-83. In: Proceedings of the 15th Lincoln College Farmers Conference.

Lambert, M.G.; Roberts, E. 1976. Aspect differences in unimproved hill country pasture. New Zealand Journal of Agricultural Research 19: 459-467.

Ledgard, S.F.; Brier, G.J.; Littler, R.A. 1987. Legume production and nitrogen fixation in hill pasture communities. New Zealand Journal of Agricultural Research 30: 413-424.

Levy, E.B.; Gorman, L.W. 1936. Strain in subterranean clover. Proceedings of the New Zealand Grassland Association 5: 19-33.

McLeod, C.C. 1967. pp. 7-8. In: New Zealand Department of Agriculture Annual Report: Field Research Section, 1966/67.

Macfarlane, M.J.; Sheath, G.W. 1984. Clovers - what type for dry hill country? Proceedings of the New 
Zealand Grassland Association 45: 140-151.

Macfarlane, M.J.; Sheath, G.W.; Tucker, M.A. 1990. Clovers for dry hill country 6 . Subterranean and white clovers at Wairakei, New Zealand. New Zealand Journal of Agricultural Research 33: 557-564.

Maunder, W.J. 1971. Elements of New Zealand's Climate. Chapter 4. In: Climates of Australia and New Zealand. World survey of climatology 13. Ed. Gentilli, J. Elsevier, New York.

Quinliven, B.J. 1971. Seed coat impermiabilty in legumes. The Journal of the Australian Institute of Agricultural Science 37: 283-295.

Quinliven, B.J.; Millington, A.J. 1962. The effect of a Mediterranean summer environment on the permiability of hardseeds of subterranean clover. Australian Journal of Agricultural Research 13: 377-387.

Rickard, D.S.; Radcliffe, J.E. 1976. Seasonal distribution of pasture production in New Zealand 12. Winchmore, Canterbury Plains dryland and irrigated pastures. New Zealand Journal of Experimental Agriculture 4: 329-335.

Rossiter, R.L. 1959. The influence of maturity grading on total yield and seed production in strains of Trifolium subterraneum L. grown as single plants or as swards. Australian Journal of Agricultural Research 10: 305-321.

Rossiter, R.L. 1978. The ecology of subterranean clover-based pastures. pp. 325-339. In: Plant relations in pastures. Ed. Wilson, J.R. CSIRO, Melbourne.

Rumball, P.J.; Cooper, B.M. 1990. Evaluation of clovers in dry hill country 2. Evaluation of subterranean and white clovers at Kaikohe. New Zealand Journal of Agricultural Research 33: 527-532.

Russell, J.S.; Moore, A.W. 1970. Detection of homoclimates by numerical analysis with reference to the brigalow region of eastern Australia. Agricultural Meteorology 7: 455-479.

Saxby, S.H. 1956. The history of subterranean clover in New Zealand. New Zealand Journal of Agriculture 92: 518-527.

Scott, D. 1985. Plant introduction trials: genotype environment analysis of plant introduction for the high country. New Zealand Journal of Experimental Agriculture 13: 117-127.

Scott, W.R. 1969. An agronomic evaluation of subterranean clover cultivars. M.Agr.Sc. Thesis, Lincoln College, University of Canterbury, New Zealand.

Sheath, G.W.; Boom, R.C. 1985a. Effects of November to April grazing pressure on hill country pastures.
1. Pasture structure and net accumulation rates. New Zealand Journal of Experimental Agriculture 13: 317-327.

Sheath, G.W.; Boom, R.C. 1985b. Effects of November to April grazing pressure on hill country pastures 3. Interrelationships with soil and pasture variation. New Zealand Journal of Experimental Agriculture 13: 341-349.

Sheath, G.W.; Macfarlane, M.J. 1990a. Evaluation of clovers in dry hill country 3 . Regeneration and production of subterranean clover at Whatawhata, New Zealand. New Zealand Journal of Agricultural Research 33: 533-539.

Sheath, G.W.; Macfarlane, M.J. 1990b. Components of subterranean clover regeneration at Whatawhata, New Zealand. New Zealand Journal of Agricultural Research 33: 541-547.

Sheath, G.W.; Macfarlane, M.J.; Crouchley, G. 1990. Evaluation of clovers in dry hill country 7. Subterranean and white clovers at Porangahau, Hawkes Bay, New Zealand. New Zealand Journal of Agricultural Research 33: 565-568.

Silsbury, J.H.; Fukai, S.1977. The effect of sowing time and sowing density on the growth of subterranean clover at Adelaide. Australian Journal of Agricultural Research 28: 427-440.

Smetham, M.L. 1968. Performance and potential use of subterranean clover strains in New Zealand. Proceedings of the New Zealand Grassland Association 30: 114-125.

Smetham, M.L. 1980. The establishment and management of subterranean clover and other annual legumes on the dry hill country of the South Island. pp. 326-346. In: Proceedings of the 30th Lincoln College Farmers Conference.

Smetham, M.L. 2003. A review of subterranean clover (Trifolium subterraneum L.); Its ecology and use as a pasture legume. Advances in Agronomy 79: 303-350.

Smetham, M.L.; Hines, S.; Jack, D.W. 1993. Seed production and autumn germination as determinants of the success of subterranean clover in a cool temperate environment. pp. 307309. In: Proceedings of the XVII International Grassland Congress.

Smetham, M.L.; Jack, D.W. 1995. Herbage production under grazing of some subterranean clover lines by comparison with lucerne. Proceedings of the Agronomy Society of New Zealand 25: 69-76.

Smetham, M.L.; Jack, D.W.; Hammond, S.E.H. 1994. The influence of patterns of flowering of some subterranean clover (Trifolium subterraneum L.) accessions and cultivars on total seed set and autumn germination in a cool temperate 
environment with sporadic summer rain. Proceedings of the New Zealand Grassland Association 56: 127-131.

Smetham, M.L.; Wu Ying, C.C.K. 1991. Establishment of subterranean clover (Trifolium subterraneum L.) in New Zealand 1. Hardseededness and autumn germination. New Zealand Journal of Agricultural Research 34: 31-44.

Smith, F.P.; Cocks, P.S.; Ewing, M.A. 1996. Short term patterns of seed softening in Trifolium subterraneum, Trifolium glomeratum and Medicago polymorpha. Australian Journal of Agricultural Research 47: 775-785.

Stevens, D.R.; Turner, J.D.; Barker, D.J.; Moloney, S. 1989. 'Grasslands Maru' phalaris: productive and persistent in hill country. Proceedings of the New Zealand Grassland Association 50: 231-236.

Suckling, F.E.T. 1959. Pasture management trials on unploughable hill country at Te Awa II Results for 1951-57. New Zealand Journal of Agricultural Research 2: 488-543.

Suckling, F.E.T.; Forde, M.B.; Williams, W.M. 1983.
Naturalised subterranean clovers in New Zealand. New Zealand Journal of Agricultural Research 26: 35-43.

White, J.G.H.; Meijer, G. 1979. Legumes and grasses for dry North Canterbury hill country. Proceedings of the New Zealand Grassland Association 40: 170-179.

Widdup, K.H.; Pennell, C. 2000. Suitability of new subterranean clovers in the Canterbury region. Proceedings of the New Zealand Grassland Association 62: 161-165.

Widdup, K.H.; Turner, J.D. 1990. Evaluation of clovers in dry hill country 11. Subterranean and white clovers on the Hokonui Hills, Southland, New Zealand. New Zealand Journal of Agricultural Research 33: 591-594.

Williams, W.M.; Sheath, G.W.; Chapman, D.F. 1990. Evaluation of clovers in dry hill country 1 . General objectives and description of sites and plant material. New Zealand Journal of Agricultural Research 33: 521-526. 